\title{
(1)

\section{The Study of glucose uptake activity in Alli chooranam (Nymphea nouchali burm.f) in L6 cell lines}

\author{
Authors \\ Janani Syamaroopa Jnanathapaswini ${ }^{1^{*}}$, Manoharan. $\mathrm{A}^{2}$ \\ ${ }^{1}$ Department of Medicine, Government Siddha Medical College, Palayamkottai,Tirunelveli, India \\ ${ }^{2}$ Vice Principal, Government Siddha Medical College, Palayamkottai, Tirunelveli, India \\ *Corresponding Author \\ Janani Syamaroopa Jnanathapaswini
}

\begin{abstract}
The Alli (Nymphea nouchali burm.f) is a well-known medicinal plant used in Siddha system of medicine for the treatment of Diabetes mellitus. The effectiveness of glucose lowering herbs is by stimulating glucose uptake by adipose and muscle tissues, hindering the glucose absorption from intestine and prohibiting glucose production from hepatocytes. This study was carried out to determine the glucose uptake activity using in vitro cell culturing methods on L6 cell lines. Treatment of the cells with plant extract significantly increased glucose uptake, the highest concentration $(100 \mu \mathrm{g} / \mathrm{ml})$ giving $46.2 \%$. $(P<0.05)$. The study concluded that aqueous extract increases glucose uptake confirms the anti-diabetic activity of Alli chooranam (N.nouchali).

Keywords: Alli, Diabetes, Glucose uptake, L6Cell line study, Nymphea nouchali, Siddha system.
\end{abstract}

\section{Introduction}

The diabetes is a progressive disease and with disease progression life style management may not be adequate, though still an integral part management, pharmacotherapy then become inevitable. World Health Organization reported (2009) that about 422 million people worldwide have suffered in diabetes \&1.6million deaths an occurred in attributed to Diabetes in every year. The Glucose uptake by GLUTs is the first step of glucose metabolism. In skeletal muscles, both insulin and contractile activity stimulate translocation of glucose transporter GLUT -4 protein from an intracellular membrane pool to the plasma membrane. Resistance to this stimulatory effect of Insulin is a major pathological feature of
Diabetes. The L6 cells are represent a good model for glucose uptake because they have been used extensively to elucidate the mechanism of glucose uptake in muscle, have an intact insulin signaling pathway and express the insulin-sensitive GLUT$4^{[6]}$

The Preparation and standardization of medicinal herbs are urgently needed for future studies and therapies. The Alli (Nymphea nouchali Bum,f) large aquatic herb of the family Nymphaeaceae, commonly known as Water lily (Alli in Tamil)is a medicinal plant widely used in Siddha which is known for its anti-diabetic activity mentioned in classical literatures. Plant distributed throughout India, Kashmir, Siberia \& Europe. An infusion of 
the flower and fruit is given in diarrhea and diaphoretic. Flowers are reputed to be antiaphrodisiac.

Although anti-diabetic activity of Alli have been reported, lack of sufficient literature on rhizome of Alli (Nymphea nouchali Burm.f) in diabetes. This study was focused on evaluating the glucose uptake activity of rhizome and flowers of Alli in L6 cell lines.

\section{Materials and Methods}

\subsection{Collection and Authentication of Plant}

The flower \& rhizome of Alli (Nymphea nouchali Burm.f) freshly collected from various places of Kerala. Identified and authenticated by the Medicinal Botanists at Government Siddha Medical College and Hospital, Palayamkottai. This herbal formulations purified according to the suitable procedure methods described in Siddha classical literature. The drug is dried and subjected to size reduction to get uniform coarse powder.

\subsection{Preparation of cell culture}

The L6 (rat myoblast cell line) cells was initially procured from National Centre for Cell Sciences (NCCS), Pune, India and maintained Dulbecco's modified Eagles medium. The cell line was cultured in $25 \mathrm{~cm}^{2}$ tissue culture flask with DMEM supplemented with $10 \%$ FBS, L-glutamine, sodium bicarbonate (Merck, Germany) and antibiotic solution containing: Penicillin (100U/ml), Streptomycin $(100 \mu \mathrm{g} / \mathrm{ml})$, and Amphoteracin B $(2.5 \mu \mathrm{g} / \mathrm{ml})$. Cultured cell lines were kept at $37^{\circ} \mathrm{C}$ in a humidified $5 \% \mathrm{CO}_{2}$ incubator.

\subsection{Glucose uptake assay}

The cells were trypsinzed $(500 \mu 1$ of $0.025 \%$ Trypsin in PBS/ 0.5mm EDTA solution for 2 minutes and passaged to $\mathrm{T}$ flasks in complete aseptic conditions. The cells were then sub cultured to a 24 well plate. After attaining $80 \%$ confluency cells were kept in DMEM without glucose for 24 hours. Samples were added to grown cells at a final concentration of 25 $\mu \mathrm{g} / \mathrm{mL}, 50 \mu \mathrm{g} / \mathrm{mL}$ and $100 \mu \mathrm{g} / \mathrm{mL}$ from a stock solution of $1 \mathrm{mg} / \mathrm{mL}$ and incubated for 24 hours in DMEM containing $300 \mathrm{mM}$ glucose. An untreated control with high glucose was also maintained. After incubation cells were isolated by spinning at $6000 \mathrm{rpm}$ for 10 minutes. Supernatant was discarded and $200 \mu \mathrm{l}$ of cell lysis buffer (1mTris Hcl, 0.25M EDTA, 2M Nacl, 0.5\% Triton) was added.

\subsection{Calculation}

The incubation was done for 30 minutes at $4{ }^{\circ} \mathrm{C}$ and the glucose uptake was estimated using high sensitivity glucose oxidase kit method (Coral Clinical Systems: Lot No; RGLU1091). All experiments were repeated in triplicates and mean average was used for calculations.

Total Glucose in $\mathrm{mg} / \mathrm{dL}=\frac{\text { Absorbance of Test }}{\text { Absobance of Standard }} \quad \mathrm{X} 100$

$$
\% \text { Glucose uptake }=\quad \frac{\text { OD of Test-OD of Control }}{\text { OD of Test }} \times 100
$$

\subsection{Statistical analysis}

Statistical analysis were carried out with one way analysis of variance and the differences between the samples determined by Dunnets multiple comparison test. The data were expressed as the mean \pm standard deviation and values were considered significant at $\mathrm{p}<0.05$.

\section{Results}

Glucose uptake in L6 cell lines was studied in invitro.

Table.1. Shows results of glucose uptake of rhizome and flowers of Alli (Nymphea nouchali Burm.f)

\begin{tabular}{|l|c|c|c|}
\hline $\begin{array}{l}\text { Concentration of } \\
\text { sample }(\mu \mathrm{g} / \mathrm{mL})\end{array}$ & Absorbance & $\begin{array}{c}\text { Glucose } \\
(\mathrm{mg} / \mathrm{dl})\end{array}$ & $\begin{array}{c}\text { \% glucose } \\
\text { uptake }\end{array}$ \\
\hline Control & 0.1077 & 36.12882 & 0.00 \\
\hline Sample code: AC-50 & 0.1202 & 40.32204 & 10.39933 \\
\hline 25 & 0.1757 & 58.93995 & 38.70233 \\
\hline 50 & 0.2013 & 67.52768 & 46.49776 \\
\hline 100
\end{tabular}

Average OD of Standard $=0.2981$ 
Table.2.Average glucose in varying concentration of plant extract

\begin{tabular}{|c|c|c|c|c|c|c|c|c|c|}
\hline $\begin{array}{l}\text { Concentrati } \\
\text { on }\end{array}$ & OD1 & OD2 & OD3 & $\begin{array}{l}\text { Glucose } \\
(\mathrm{mg} / \mathrm{dL})\end{array}$ & $\begin{array}{l}\text { Glucose } \\
(\mathrm{mg} / \mathrm{dL})\end{array}$ & $\begin{array}{l}\text { Glucose } \\
(\mathrm{mg} / \mathrm{dL})\end{array}$ & $\begin{array}{l}\text { Average } \\
\text { (Glucose } \\
(\mathrm{mg} / \mathrm{dL}))\end{array}$ & stdev & Error \\
\hline Control & 0.1114 & 0.1027 & 0.109 & 37.37 & 34.4515 & 36.56491 & 36.1288 & 1.507333 & 0.502444 \\
\hline 25 & 0.1161 & 0.1254 & 0.1191 & 38.9466 & 42.0664 & 39.953 & 40.322 & 1.592297 & 0.530766 \\
\hline 50 & 0.1798 & 0.1646 & 0.1827 & 60.3153 & 55.2163 & 61.2881 & 58.9399 & 3.261209 & 1.08707 \\
\hline 100 & 0.2077 & 0.211 & 0.1852 & 69.6746 & 70.7816 & 62.1268 & 67.52767 & 4.709924 & 1.569975 \\
\hline
\end{tabular}

Figure.1 Average glucose in varying concentration of plant extract

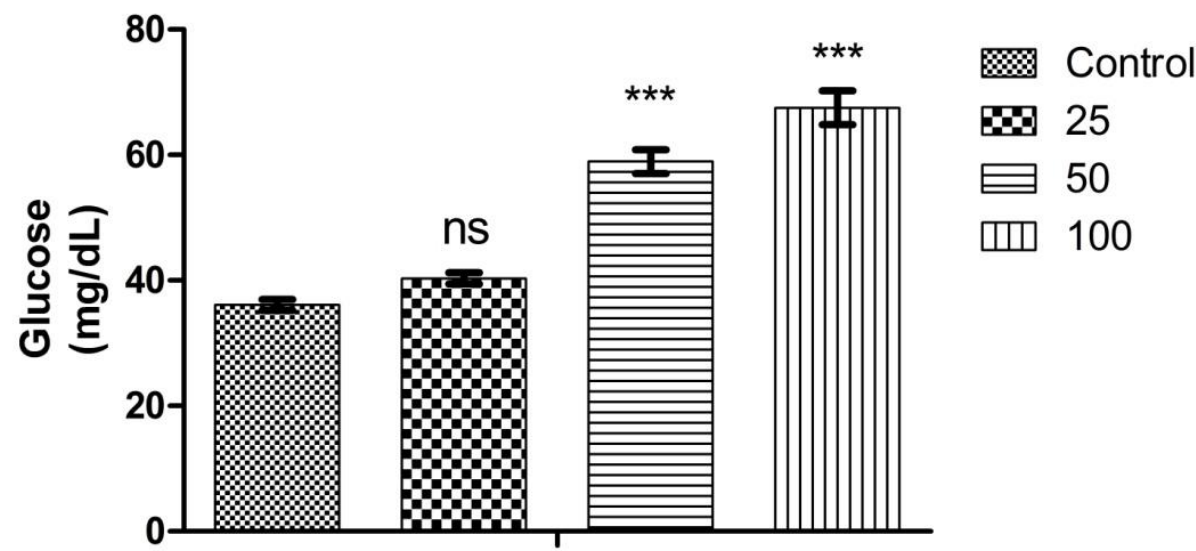

Concentration of sample $(\mu \mathrm{g} / \mathrm{mL})$

Table 3 Percentage of glucose uptake in varying concentration of plant extract

\begin{tabular}{|l|c|c|c|c|c|c|}
\hline Concentration & $\begin{array}{c}\text { Percentage } \\
\text { of glucose } \\
\text { uptake 1 }\end{array}$ & $\begin{array}{c}\text { Percentage } \\
\text { of glucose } \\
\text { uptake 2 }\end{array}$ & $\begin{array}{c}\text { Percentage } \\
\text { of glucose } \\
\text { uptake 3 }\end{array}$ & Average & St dev & Std error \\
\hline Control & 0 & 0 & 0 & 0 & 0 & 0 \\
\hline 25 & 4.048234 & 18.10207 & 8.480269 & 10.21019 & 7.18485 & 2.39495 \\
\hline 50 & 38.04227 & 37.60632 & 40.33935 & 38.66265 & 1.46834 & 0.489447 \\
\hline 100 & 46.36495 & 51.32701 & 41.14471 & 46.27889 & 5.091698 & 1.697233 \\
\hline
\end{tabular}

Figure.2 Percentage of glucose uptake in varying concentration of plant extract

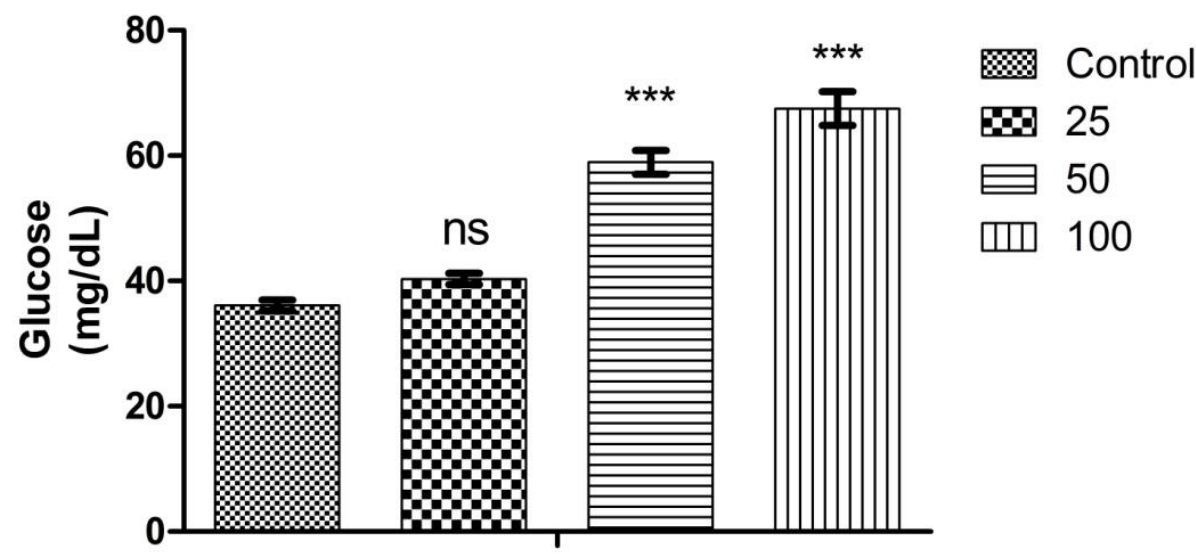

Concentration of sample $(\mu \mathrm{g} / \mathrm{mL})$ 


\section{Discussion}

In the present study significant glucose uptake was recorded for L6 cells at different concentrations $50 \mu \mathrm{g} / \mathrm{ml}$ and $100 \mu \mathrm{g} / \mathrm{ml}$. With the highest concentration $(100 \mu \mathrm{g} / \mathrm{ml})$ giving increased uptake 46.2\% ( $\mathrm{P}<0.0001)$. The result obtained in this study on glucose uptake using L6 cells demonstrated that Alli (Nymphea nouchali Burm.f) increased glucose uptakeinL6 cell lines.

\section{Conclusion}

Findings suggests that Alli (Nymphea nouchali Burm.f) exhibits in anti-diabetic activity might be due its phytochemical constituents. This supports the usage of this plant as an alternative in the treatment of Diabetes. More studies are required to confirm its mechanism of action thereby providing alternative therapy to contribute normal blood sugar and prevention of diabetic complications.

\section{Acknowledgements}

The authors would like to acknowledge Biogenix Research Center, Trivandrum for providing and guiding us with the necessary lab facilities.

\section{Conflict of interest}

The authors declare no conflict of interest in the present work.

\section{References}

1. Idowu Jonas Sagbo, Marynavan de ventor, Trevor koekomoer et al In vitro antidiabetic activity and mechanism of action of Brachylaena elliptica (thumb.) DC, Evidence based complementary and alternative medicine, Jul 4

2. Mabel parimala, Francis Gricilda Sobha 2014,Evaluation of antidiabetic potential of Nymphea nouchali Burm fseeds in STZ induced diabetic rats, International journal of pharmacy and pharmaceutical sciences, vol6(4)
3. Murugesa Muthaliyar KS, 1936, Gunapadam (MutharPagam-Mooligai Vaguppu), Directorate of Indian Medicine and Homeopathy, Chennai, $2^{\text {nd }}$ edition, 43

4. Panda H, Handbook on MedicinalHerbs with uses, Asian pacific business press

5. Pulliah, Chandrasekhar Naidu, 2012, Ant diabetic plants in India, 978-81-87498-674.

6. R.N. Guptha, Anilpareek, Manish Suthar, Garvendra SRathor 2009,Study of glucose uptake activity of Helictres isora Linn.fruits in L6 cell lines, Int J Diabetes Dev Ctries Oct-Dec;29(4):170-173

7. Rajeev Chawla, Manual of Diabetes care, Jaypee Brothers MedicalPublishers,2014,1

8. Soumya G,Dr Solomon Sunder Raj 2012,Antidiabetic activity of ethanolic extract of Nymphea lotus roots on streptozotocin induced Diabetic rats, Journal of Pharmacy research,5(9),46954696.

9. Tafadzwa Taderera, Exnevia gomo et al, Annona stenophylla aqueous extract stimulate glucose uptake in established $\mathrm{C} 2 \mathrm{Cl} 2$ muscle celllines, African Health Sciences,2019 Jun;19(2):2219-2229

10. YamamotoN,Ueda-Wakagi $M$ et al, Measurement of glucoseuptake inculturedcells, Curr ptotoc pharmacol, 2015,Dec 8;71:12,14,1doi 10. 